\title{
International Capital Movements: Who Gains and Who Loses?
}

\author{
Morihiro Yomogida $\mathrm{a}^{\mathrm{a}^{*}}$
}

${ }^{a}$ Sophia University

\begin{abstract}
In this paper, I explore the impacts of international capital flows on income distribution within countries. Using a simple Ricardian setting with sector-specific capital, I examine whether the owners of capital and workers gain or lose from capital movements relative to a free trade baseline. I show that the structure of commodity demand plays a crucial role in determining the distributional effect of international capital movements.
\end{abstract}

JEL classification: F11, F21

Keywords: the Ricardian model of trade, capital movements, income distribution

\section{Introduction}

In the recent wave of globalization, production factors such as capital and skilled or unskilled workers are gradually allowed to move internationally. The movement of production factors clearly affects income distribution within as well as across nations. As a result, economists and policy makers have paid more attention to the distributional effects of factor movements. ${ }^{1}$ What is the impact of factor movements on income distribution within nations? For the investigation of this issue, I use a simple general equilibrium model.

If production factors are trapped within countries, the principle of comparative advantage predicts the pattern of trade. If some of production factors are mobile internationally,

* I am grateful to Ronald Jones and participants at the APJAE Symposium on International Trade in Honor of Prof. Ronald Jones for valuable comments. I would also like to thank seminar participants at Hitotsubashi University and Kwansei Gakuin University for useful suggestions. Address: Faculty of Economics, Sophia University, 7-1 Kioi-cho, Chiyoda-ku, Tokyo 102-8554, Japan. Fax: +81-3-3238-4647. Email: m-yomogi@sophia.ac.jp.

${ }^{1}$ In an article in the New York Times (2004), Charles Schumer (the senior Senator from New York state) and Paul Craig Roberts state, "American jobs are being lost not to competition from foreign companies, but multinational corporations, often with American roots, that are cutting costs by shifting operations to low-wage countries". 
absolute advantage as well as comparative advantage plays a role in determining the pattern of trade in goods and factors. Using a two-country Ricardian model with sectorspecific capital, I explore the impact of capital movements on the distribution of income within nations.

There is extensive theoretical work on trade and capital mobility, including Mundell (1957), Purvis (1972), Uekawa (1972), Jones and Ruffin (1975), Markusen (1983), Jones and Dei (1983), Ohyama (1989), Suzuki (1989), Neary (1995), and Jones (2000) among others. ${ }^{2}$ In particular, this paper is related to Jones $(1980,1994)$. He extends a Ricardian model to a setting in which one sector requires sector-specific capital in addition to labor. Using this extended model, he shows that absolute advantage as well as comparative advantage plays a role in the determination of capital allocation in a world. In his work, the terms of trade in goods are treated as an exogenously given parameter. In this paper, I explicitly consider a simple structure of commodity demand so that the terms of trade in goods are determined endogenously in goods markets. This extension allows us to analyze the role of the demand structure in determining the direction of international capital movements. Also, it enables us to examine whether or not the owners of capital and workers gain from capital flows relative to a free trade baseline.

The rest of this paper is organized as follows. In Section 2, I develop the model. In Section 3, I examine free trade equilibrium in a regime in which capital is not allowed to move between countries. In Section 4, I allow capital to move internationally and examine free trade equilibrium with international capital mobility. I also analyze the effect of capital movements on income distribution within countries. In Section 5, I close this paper with concluding remarks.

\section{The Model}

Let us consider a simple Ricardian setting. There are two sectors, $X$ and $Y$. Sector $X$ requires capital as well as labor in production. Sector $Y$ uses labor only. ${ }^{3}$ Since only sector $X$ uses capital, capital is a sector-specific input. Labor moves between two sectors since it is required in both sectors. There are two countries, Home and Foreign. Each country is endowed with fixed units of labor and capital. Let $L$ denote the supply of labor at Home. The full employment constraint states

$$
a_{L X} X+a_{L Y} Y \leqq L,
$$

where $a_{L j}$ units of labor are required to produce one unit of $\operatorname{good} j(j=X, Y)$, and $X(Y)$ is the output of sector $X(Y)$ at Home. If capital is not allowed to move between countries, there is another constraint,

$$
a_{K X} X \leqq K,
$$

\footnotetext{
${ }^{2}$ See Jones (2000) for recent developments on this topic.

${ }^{3}$ We may refer to capital as skilled labor and labor as unskilled labor. Then, good $X$ is skilled-labor intensive relative to good $Y$.
} 
where $a_{K X}$ units of capital are required to produce one unit of $X$, and $K$ units of capital exist at Home. The demand for capital must be equal to or less than the Home supply of capital. If there is plenty of capital at Home, the capital constraint may not matter at all for production patterns. To avoid this situation, we assume that the following condition holds,

$$
K<\frac{a_{K X}}{a_{L X}} L \equiv K_{M}
$$

where $K_{M}$ is the maximum capacity for the use of capital at Home. This condition implies that the capital constraint determines the maximum capacity for the output of $X$. Similarly, we can derive labor and capital market constraints for Foreign,

$$
\begin{aligned}
& a_{L X}^{*} X^{*}+a_{L Y}^{*} Y^{*} \leqq L^{*}, \\
& a_{K X}^{*} X^{*} \leqq K^{*},
\end{aligned}
$$

where asterisks denote variables associated with Foreign. We assume that Foreign is endowed with capital, the amount of which is smaller than the maximum capacity for the use of capital at Foreign,

$$
K^{*}<\frac{a_{K X}^{*}}{a_{L X}^{*}} L^{*} \equiv K_{M}^{*} .
$$

Using these labor and capital constraints, we can illustrate a production possibility frontier for each country. In Figure 1(a), the solid line shows the production possibility frontier for Home., ${ }^{4,5}$ The maximum output of $\mathrm{X}$ is equal to $K / a_{K X}$. Figure $1(\mathrm{~b})$ shows the production possibility frontier for Foreign. Notice that the slope of the labor constraint of Home is flatter than that of Foreign. This reflects that Home has a comparative advantage in producing $X$ in terms of labor productivity,

$$
\frac{a_{L X}}{a_{L Y}}<\frac{a_{L X}^{*}}{a_{L Y}^{*}} .
$$

${ }^{4}$ Figures 1 through 5 are all drawn with the following parameters: Home $L=50, K=30, a_{L X}=5, a_{K X}=5$, $a_{L Y}=10$. Foreign $L^{*}=50, K^{*}=5, a_{L X}^{*}=10, a_{K X}^{*}=2.5, a_{L Y}^{*}=5$.

${ }^{5}$ In this numerical example, we assume that $K_{M}^{*}<K+K^{*}<K_{M}$ holds. This assumption implies that only Home can "absorb" all of capital existing in the world if international capital mobility is allowed. It is also possible to consider other cases, (1) $K_{M}^{*}<K+K^{*}, K_{M}<K+K^{*}$, and $K+K^{*}<K_{M}+K_{M}^{*}$, and (2) $K_{M}^{*}>K+K^{*}, K_{M}>K+K^{*}$. These alternative assumptions do not affect qualitatively most of results obtained in the following analysis. 
Figure 1(a): Home PPF

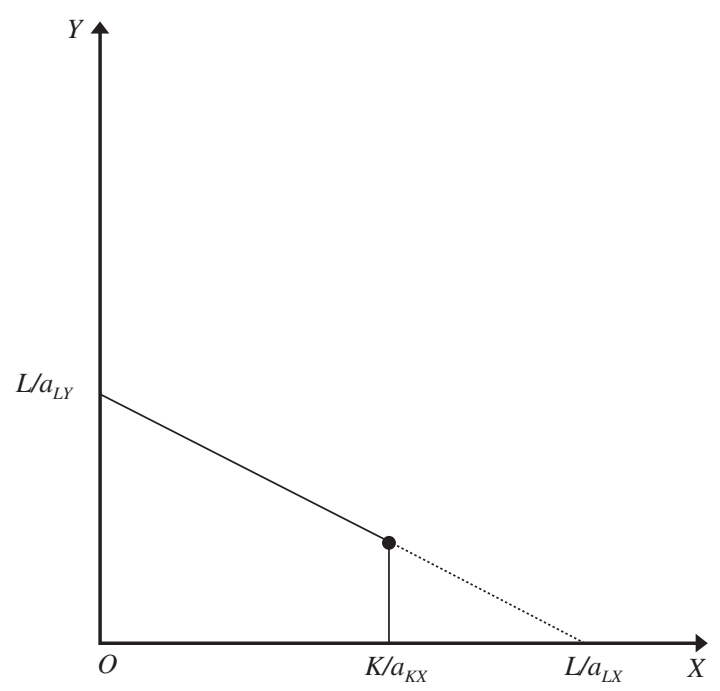

Figure 1(b) Foreign PPF

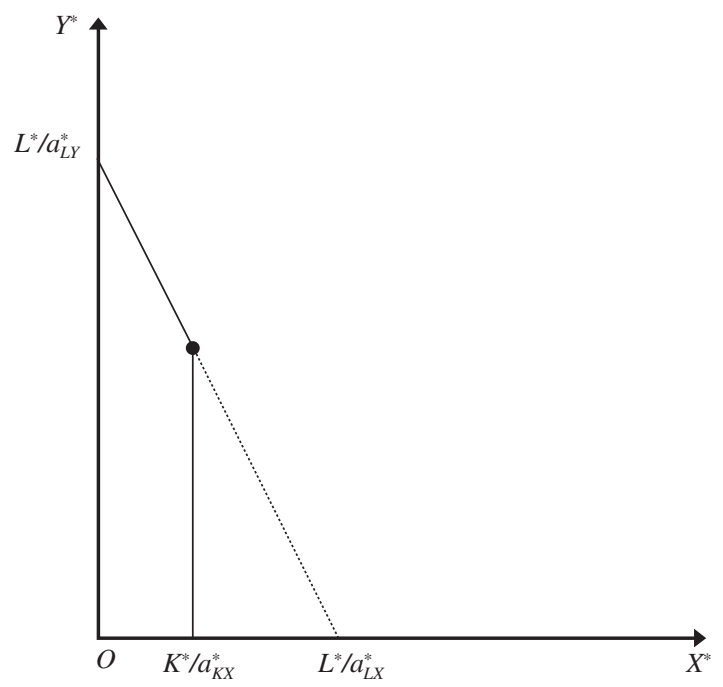

We assume that this condition holds in the following analysis. In addition to the labor constraint, the capital constraint does matter for production patterns. This implies that absolute capital productivity as well as comparative labor productivity plays an important role in the determination of production structures. It is possible to consider two different scenarios. First, Home has a comparative advantage in $X$ in terms of labor productivity, but 
Foreign has an absolute advantage in $X$ in terms of capital productivity. Second, Home has an absolute advantage in terms of capital productivity as well as a comparative advantage in terms of labor productivity in producing $X$. We shall focus on the first scenario since it is more interesting. ${ }^{6}$ Thus, we assume that

$$
a_{K X}^{*}<a_{K X}
$$

In Figure 1, the maximum output of $X$ at Foreign is smaller than that at Home. This implies that Home has the larger amount of capital than Foreign, and as a result, it has the greater capacity for $X$ even though it has an absolute capital disadvantage in $X$.

Since markets are perfectly competitive, the following competitive conditions must be satisfied at equilibrium,

$$
\begin{aligned}
& p_{X} \leqq w a_{L X}+r a_{K X}, \\
& p_{Y} \leqq w a_{L Y},
\end{aligned}
$$

where $p_{j}$ is the price of good $j(j=X, Y), w$ is wage rate, and $r$ is the return to capital. If both goods are produced at equilibrium, the competitive conditions (7) and (8) hold with equality, and the following equation is derived,

$$
\frac{p_{X}}{p_{Y}}=\frac{a_{L X}}{a_{L Y}}+a_{K X} \frac{r}{p_{Y}} .
$$

The relative cost of good $X$ is decomposed into two parts. On the RHS, the first term represents the relative labor productivity and the second term represents the capital costs in terms of good $Y$. This implies that absolute capital productivity as well as comparative labor productivity plays an important role in the determination of production costs. Similarly, we can derive competitive conditions for Foreign,

$$
\begin{aligned}
& p_{X} \leqq w^{*} a_{L X}^{*}+r^{*} a_{K X}^{*}, \\
& p_{Y} \leqq w^{*} a_{L Y}^{*} .
\end{aligned}
$$

If Foreign produces both goods at equilibrium, the following equation is obtained as well,

$$
\frac{p_{X}}{p_{Y}}=\frac{a_{L X}^{*}}{a_{L Y}^{*}}+a_{K X}^{*} \frac{r^{*}}{p_{Y}} .
$$

\footnotetext{
${ }^{6}$ In the second scenario, Home would necessarily import capital from Foreign. However, in the first scenario, this is not true.
} 
In Figure 2, the two conditions $(\mathrm{AH})$ and $\left(\mathrm{A}^{*} \mathrm{~F}\right)$ are illustrated in the space of the return to capital in terms of good $Y$ and the relative price of good $X$. The slope of each line is determined by the absolute productivity of capital. The intercept at the vertical axis is determined by the comparative labor productivity, i.e., $O A=a_{L X} / a_{L Y}$ and $O A^{*}=a_{L X}^{*} / a_{L Y}^{*}$ I have assumed that Home has the higher comparative labor productivity in $X$ but Foreign has the higher absolute capital productivity in X. Under this assumption, $(\mathrm{AH})$ has a steeper slope but lower intercept than $\left(\mathrm{A}^{*} \mathrm{~F}\right)$, and thus the two lines intersect with each other in the first quadrant. Solving $(\mathrm{AH})$ and $\left(\mathrm{A}^{*} \mathrm{~F}\right)$ simultaneously for $p_{X} / p_{Y}$, we can obtain

$$
O B=\frac{a_{L X}}{a_{L Y}}+\left[\frac{a_{K X}}{a_{K X}-a_{K X}^{*}}\right]\left[\frac{a_{L X}^{*}}{a_{L Y}^{*}}-\frac{a_{L X}}{a_{L Y}}\right]
$$

Figure 2: The relative price of $\operatorname{good} X$ and the returns to capital

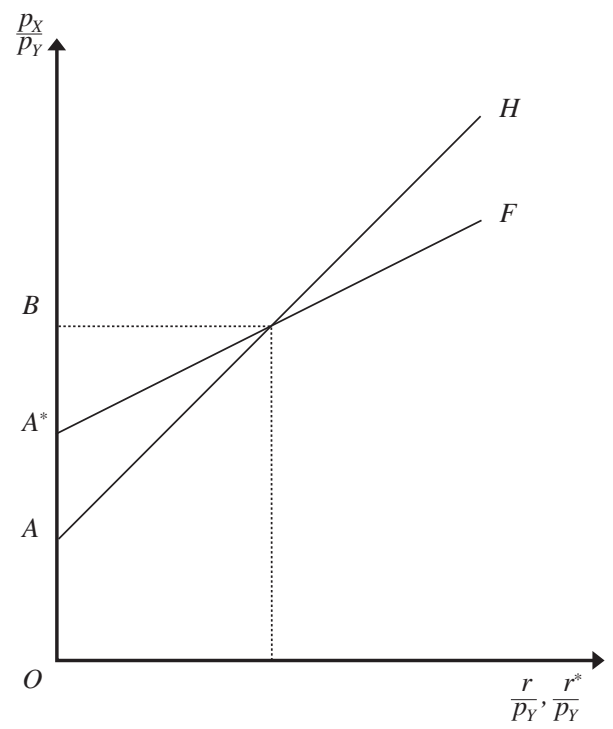

Figure 2 shows that Home can offer the higher return to capital than Foreign when $p_{X} / p_{Y}$ is smaller than $O B$. This suggests that comparative as well as absolute advantage plays a role in determining the direction of capital movements.

Finally, let us turn to preferences of consumers. Countries are assumed to have identical preferences that are represented by a Cobb-Douglas utility function,

$$
u=C_{X}^{\alpha} C_{Y}^{1-\alpha}, 0<\alpha<1,
$$

where $C_{j}$ denotes the consumption quantity of $\operatorname{good} j(j=X, Y)$. 


\section{Free Trade Equilibrium}

In this section, we consider a situation in which goods are freely tradable but capital is not allowed to move between countries. For the investigation of free trade equilibrium, it is useful to illustrate the relative demand and supply curves. In Figure 3, RS1 is the relative supply curve of the world. When $p_{X} / p_{Y}$ is smaller than $O A=\frac{a_{L X}}{a_{L Y}}$, both countries specialize in producing good $Y$. As $p_{X} / p_{Y}$ rises, Home starts producing good $X$ due to its comparative labor advantage. If $O A<p_{X} / p_{Y}<O A^{*}$, then Home produces both goods, but Foreign still specializes in producing good $Y$. Further increases in $p_{X} / p_{Y}$ induce either country to produce good $X$. When $p_{X} / p_{Y}>O A^{*}$, Home and Foreign produce both goods. Unlike the usual Ricardian model, countries do not specialize in producing good $X$. This is because the capital constraint does bind in each country before all of labor supplies are absorbed in sector $X$.

Figure 3: The equilibrium without international capital mobility

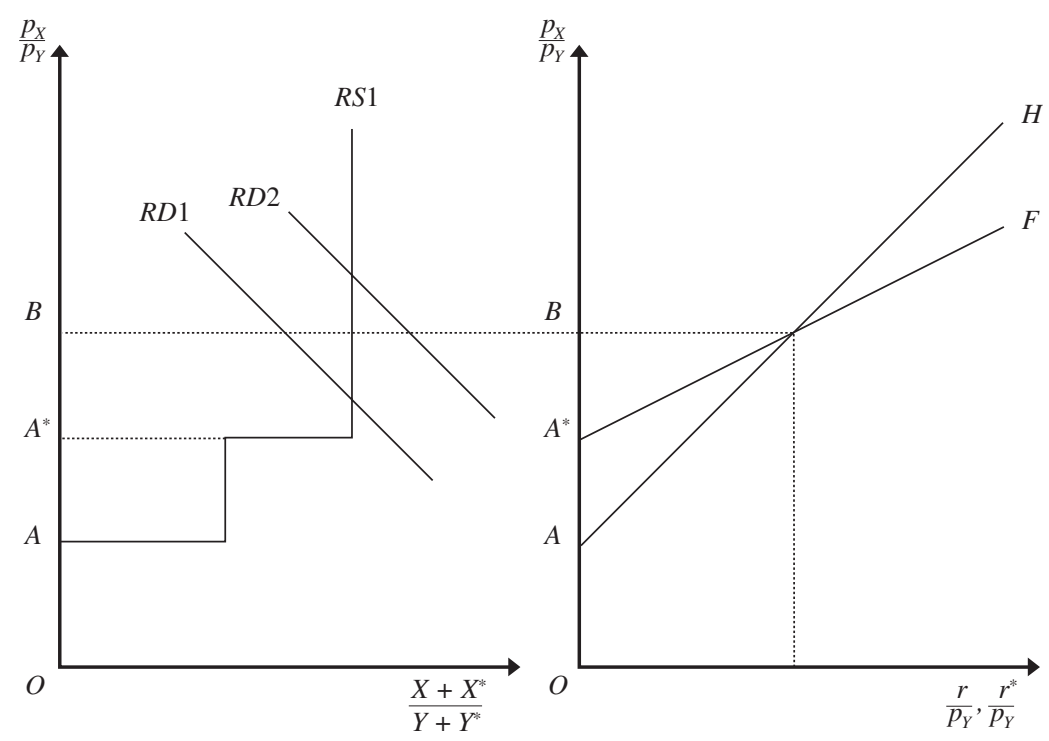

Let us turn to the demand side. Given the utility function (12), the relative demand for $\operatorname{good} X$ in the world is represented by

$$
\frac{C_{X}+C_{X}^{*}}{C_{Y}+C_{Y}^{*}}=\left(\frac{\alpha}{1-\alpha}\right)\left(\frac{p_{Y}}{p_{X}}\right) .
$$

We shall focus on a case in which countries are incompletely specialized in production. There are two types of equilibria. First, suppose that the expenditure share of good 
$X$ is small and the relative demand curve of the world is given by RD1 in Figure 3. Then, in the free trade equilibrium at which RS1 intersects with RD1, countries produce both goods, and Home offers the higher return to capital than Foreign. This implies that capital would flow into Home from Foreign under free capital mobility. Second, suppose that the share of expenditure of good $X$ is large and the relative demand curve of the world is given by RD2 in Figure 3. Then, in contrast to the previous case, Foreign offers the higher return to capital than Home at the free trade equilibrium, which implies that capital would flow into Foreign from Home.

\section{Capital Movements}

In this section, we shall consider a situation in which capital mobility as well as goods trade is allowed between countries. As we have shown in Figure 3, the direction of capital movements crucially depends on the size of the relative demand. If the expenditure share of good $X$ is small and the relative demand curve is given by RD1, then Foreign would export capital to Home. On the other hand, if the share of expenditure on good $X$ is sufficiently large and the relative demand curve is given by RD2, then Home would export capital to Foreign.

First, let us consider how international capital movements affect the shape of the relative supply curve. In Figure 4, the relative supply curve under capital mobility is drawn as RS2. The direction of capital movements depends on the relative price of good $X$. If $p_{X} / p_{Y}$ is smaller than $\mathrm{OB}$, Home offers the higher return, and thus it attracts capital from Foreign. Eventually, all of capital moves to Home since it has a sufficiently large capacity. ${ }^{7}$ Then, the relative supply of good $X$ in the world is

$$
O C=\frac{\left(K+K^{*}\right) / a_{K X}}{L / a_{L Y}-a_{L X}\left(K+K^{*}\right) / a_{K X} a_{L Y}+L^{*} / a_{L Y}^{*}}
$$

\footnotetext{
${ }^{7}$ Remember that $K+K^{*}<K_{M}$
} 
Figure 4: The relative supply curve is $R S 2$ under capital movements

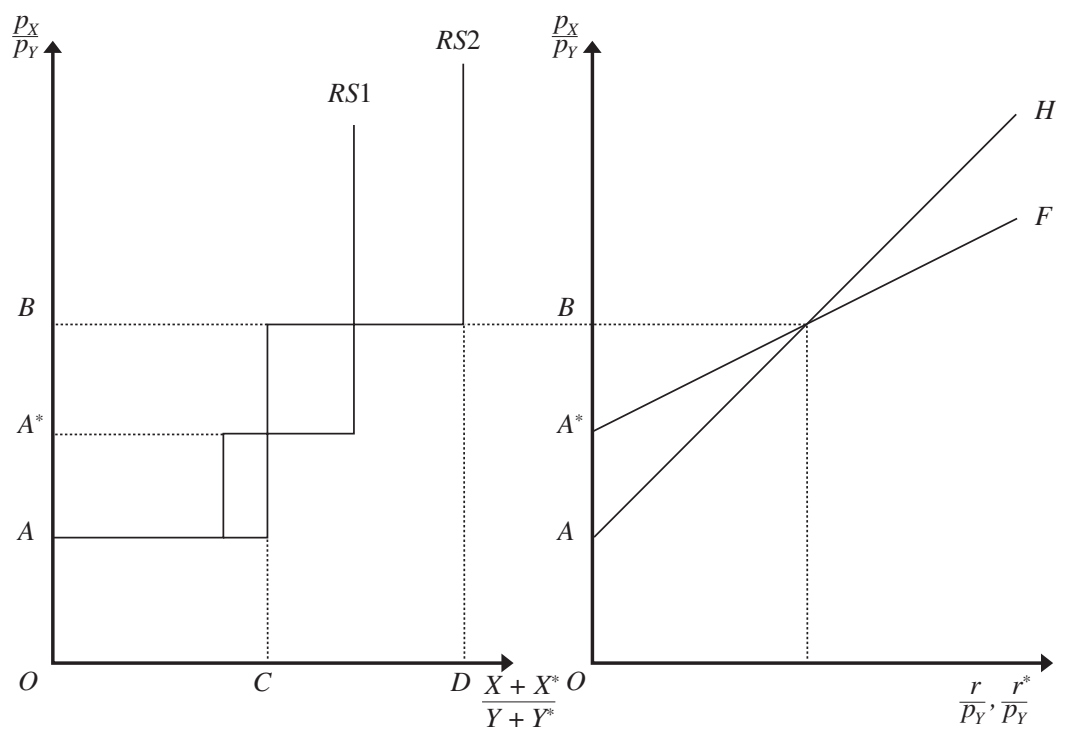

The production of good $X$ concentrates in Home, and Foreign is driven to specialize in producing good $Y$. On the other hand, if the relative price of good $X$ is sufficiently high, then the direction of capital flows is reversed. When $p_{X} / p_{Y}$ is greater than $O B$, capital flows into Foreign. Since Foreign does not have a sufficiently large capacity, some of capital remains in Home. ${ }^{8}$ Then, the relative supply of $\operatorname{good} X$ is

$$
O D=\frac{\left(K+K^{*}-a_{K X}^{*} L^{*} / a_{L X}^{*}\right) / a_{K X}+L^{*} / a_{L X}^{*}}{L / a_{L Y}-a_{L X}\left(K+K^{*}-a_{K X}^{*} L^{*} / a_{L X}^{*}\right) / a_{K X} a_{L Y}} .
$$

Foreign is driven to specialize in producing good $X$, and Home produces both good $X$ and $Y .^{9}$ Finally, when $p_{X} / p_{Y}$ equals $O B$, both countries offer the same return to capital. Then, the world relative supply curve becomes horizontal at $O B$ and incomplete specialization can occur at either country. When the relative output of good $X$ equals $O C$ in Figure 4, all of capital is located in Home and Foreign produces good $Y$ only. As capital moves to Foreign from Home, the relative output of good $X$ expands, and eventually, Foreign specializes in producing good $X$ at point $\mathrm{D}$ in Figure $4 .{ }^{10}$

\footnotetext{
${ }^{8}$ Recall that $K+K^{*}>K_{M}^{*}$

${ }^{9}$ It is easy to show that $O D>O C$ given (A1) and (A2).

${ }^{10}$ The reallocation of capital from Home to Foreign raises the world output of good $X$ because Foreign has the higher productivity of capital than Home. At the same time, the production of good $Y$ shifts to Home from Foreign, but this reduces the world output of good $Y$ since Home has a comparative disadvantage in producing good $Y$.
} 
Figure 5: The equilibrium with capital mobility

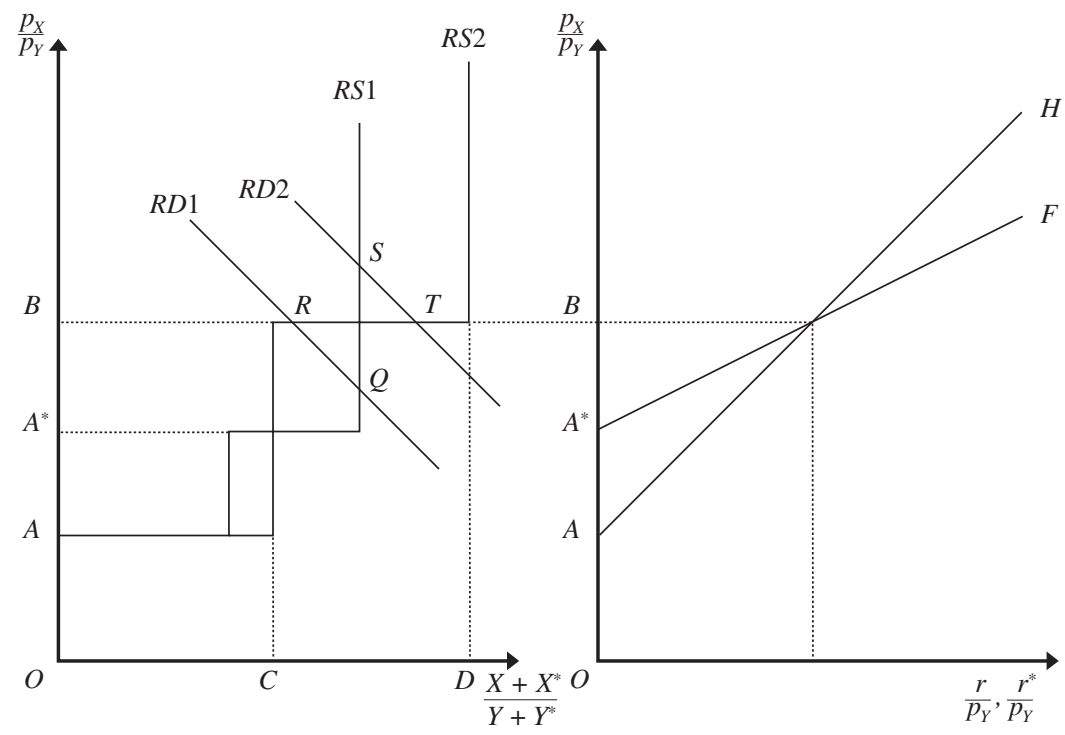

Now, we are ready to show free trade equilibrium with capital mobility. Figure 5 shows how equilibrium changes due to capital movements. Let us first consider a case in which the relative demand curve is given by RD1. When countries trade goods only, the relative supply curve is illustrated as RS1 and thus the equilibrium is point $Q$. At the equilibrium, the return to capital is higher in Home than in Foreign. Thus, if capital markets are opened up, Home imports capital from Foreign. Under capital mobility, the relative supply curve is drawn as RS2, and thus the equilibrium turns out to be point $R$. Clearly, due to capital movements, the relative price of good $X$ rises, which leads to an increase in the return to capital in both countries.

Next, suppose that the relative demand curve is given by RD2. Before capital markets are opened up, the equilibrium is point $S$, and Foreign offers the higher return to capital than Home. When capital mobility is allowed, Foreign imports capital from Home. The relative supply curve is illustrated as RS2, and thus the equilibrium turns out to be point $T$. Clearly, capital movements reduce the relative price of good $X$, which results in a fall in the return to capital in either country.

\subsection{The effect of capital movements on income distribution}

It is easy to show how capital movements affect income distribution within countries. Suppose that good $Y$ is numeraire, and thus $p_{Y}=1$. Since both countries are incompletely specialized before and after capital movements, the wage rate for labor is fixed by labor productivity of good $Y$,

$$
w=\frac{1}{a_{L Y}}, w^{*}=\frac{1}{a_{L Y}^{*}} .
$$


The competitive conditions for good $X,(7)$ and (9), hold with equality as well. Then, with those conditions, we can derive

$$
\hat{p}_{X}=\theta_{L X} \hat{w}+\theta_{K X} \hat{r},
$$

where $\theta_{i X} \in[0,1]$ is the share of factor $i(i=K, L)$ in the price of good $X$, and $\hat{z}$ denotes $d z / z$, a relative change in a variable $z$. When the expenditure share of good $X$ is small and the relative demand curve for good $X$ is given by RD1, we have shown that $\hat{p}_{X}>\hat{w}=0$ due to capital movements. Given this result, (17) implies that $\hat{r}>\hat{p}_{X}>\hat{w}=0$. Thus, if the demand for the capital intensive good is weak, the owners of capital gain but workers lose due to the liberalization of international capital movements.

Next, suppose that the share of expenditure of $\operatorname{good} X$ is large and the relative demand curve is given by RD2. Since the relative price of $\operatorname{good} X$ falls due to capital flows, workers in either country gain. However, the owners of capital lose since (17) implies that $\hat{r}<\hat{p}_{X}<\hat{w}=0$. Therefore, if the demand for the capital intensive good is strong, capital movements hurt the owners of capital but benefit workers in either country.

\section{Concluding Remarks}

I have incorporated the structure of commodity demand into the simple Ricardian framework developed by Jones (1980). This allows us to examine when international capital movements benefit or hurt the owners of capital and workers in countries that trade goods and capital with each other. If countries are incompletely specialized in production and the world demand for the capital intensive good is strong, capital flows into the country having the higher capital productivity and the world production of capital intensive good expands. As a result, the capital intensive good becomes less expensive, which benefits workers but hurts the owners of capital. However, if the demand for the capital intensive good is weak, the direction of capital movements is reversed, and the effects on income distribution are totally opposite.

It is also possible to examine how capital movements affect the pattern and volume of trade in goods. The present framework is useful to show how the demand structure plays a role in determining the direction of capital flows. This feature allows us to examine how a change in the pattern of demand affects trade in goods by inducing international capital movements. However, it is beyond the scope of this paper to examine this issue, and it is left for our future work.

\section{References}

Caves, R., 1971, "International Corporations: the Industrial Economics of Foreign Investment", Economica 38, 1-27.

Davis, D. and D. Weinstein, 2002, "Technological Superiority and the Losses from Migration", NBER Working Paper Series 8971.

Ikema, M., 1969, "The Effect of Economic Growth on the Demand for Imports: A Simple

Diagram", Oxford Economic Papers 21, 66-69. 
Jones, R., 1980, “Comparative and Absolute Advantage”, Swiss Journal of Economics and Statistics, 116, no. 3, 235-260.

Jones, R., 1994, “Trade and Capital Mobility: A Ricardian Setting”, Nagasaki Prefectural University Review 28, 77-89.

Jones, R., 2000, Globalization and the Theory of Input Trade (Cambridge Mass.: The MIT Press).

Jones, R. and F. Dei, 1983, "International Trade and Foreign Investment: A Simple Model”, Economic Inquiry 21, 449-464.

Jones, R. and R. Ruffin, 1975, “Trade Patterns and Capital Mobility”, in M. Parkin and A. R. Nobay (eds.), Current Economic Problems (Cambridge University Press).

Jones, R. and R. Ruffin, 2004, "International Technology Transfer: Who Gains and Who Loses?", University of Rochester, mimeo.

Kemp, M. and K. Shimomura, 1988, "The Impossibility of Global Absolute Advantage in the Heckscher-Ohlin Model of Trade", Oxford Economic Papers 40, 575-576.

Kemp, M., Y. Ng, and K. Shimomura, 1993, “The International Diffusion of the Fruits of Technical Progress", International Economic Review 34, 381-385.

Markusen, J., 1983, "Factor Movements and Commodity Trade as Complements", Journal of International Economics 19, 341-356.

Mundell, R., 1957, "International Trade and Factor Mobility", American Economic Review 47, 321-335.

Neary, J.P., 1995, "Factor Mobility and International Trade", Canadian Journal of Economics 28, S4-S23.

Ohyama, M., 1989, "Factor Endowments and the Pattern of Commodity and Factor Trade", Keio Economic Studies 23, 57-60.

Purvis, D., 1972, “Technology, Trade, and Factor Mobility”, Economic Journal 82, 991-999.

Schumer, C. and P. C. Roberts, 2004, "Second Thoughts on Free Trade", New York Times, January 6, 2004.

Suzuki, K., 1989, "Choice between International Capital and Labor Mobility for Diversified Economies", Journal of International Economics 27, 347-361.

Uekawa, Y., 1972, “On the Existence of Incomplete Specialization in International Trade with Capital Mobility”, Journal of International Economics 2, 1-24. 